\title{
Application of NRCS Model to Watershed Having No Landcover Data
}

\author{
Parthasarathi Choudhury \\ Professor, Department of Civil Engineering, National Institute of Technology \\ Silchar, Assam, India
}

Tel: 91-943-537-2651Ｅ-mail:ps_chou@yahoo.com

Jotish Nongthombam (Corresponding author)

Department of Civil Engineering, National Institute of Technology

Silchar, Assam, India

Tel: 91-986-441-6747Ｅ-mail: jnongthombam@gmail.com

Received: May 28, 2010 Accepted: June 18, 2010

doi:10.5296/emsd.v1i2.1842ＵRL: http://dx.doi.org/10.5296/emsd.v1i2.1842

\begin{abstract}
In the present study NRCS model is applied with a velocity factor estimation technique that relies on length and slope characteristics of a watershed. As given by Kirpich formula and velocity relationship characteristics flow velocity for a watershed can be estimated directly by using length and slope values. The model is applied to derive 1-hr UH for Madhura and Ghagra watersheds located in Barak basin in India. Drainage network for the watersheds and the geomorphologic parameters are estimated using 30m-ASTER DEM. Length and average slope values for the watersheds are estimated using GIS technique. UH peak characteristics values obtained is compared with earlier GIUH results, comparison of the results show that NRCS model when used with velocity factor estimated on the basis of length and slope characteristics give similar results. Incorporation of new velocity parameter estimation technique allows applying NRCS model to watersheds having no landcover data making it more useful for ungauged watersheds.
\end{abstract}

Keywords: Unit hydrograph, ungauged, watershed, time of concentration, Geographic Information System 


\section{Introduction}

Storm runoff hydrograph depicts response of a watershed due to a rainfall event and is required for various purposes such as, planning and designing of hydraulic structures, modeling flood flow, sediment flow; flood and erosion control studies and for assessing flood risk and venerability of different hydraulic structures etc. Unit hydrograph (UH) represents runoff response resulting from a unit rainfall excess and is used to estimate the surface runoff hydrograph for a drainage basin. This process of determining surface runoff for a drainage basin due to a particular storm is commonly referred to as rainfall-runoff analysis. In the rainfall-runoff analysis a watershed is considered as a hydrologic system with parameters varying in space and time domains. Distributed parameter modeling technique is required to estimate watershed runoff hydrograph. Past stream flow records provide valuable hydrologic information and are useful in modeling runoff for a watershed; in the case of an ungauged watershed stream flow records being unavailable the modeling task becomes more difficult.

Researchers have used different models and techniques that mainly rely on watershed characteristics to develop rainfall-runoff models for ungauged watersheds. Among several attempts that have been made towards establishing relationships between hydrologic characteristics and the geomorphologic parameters of a watershed ( Bernard 1935, Snyder 1938, Taylor and Schwarz 1952, Boyd et al. 1979,1987), geomorphologic instantaneous unit hydrograph (GIUH), a pioneering concept linking quantitative geomorphology with the watershed hydrologic characteristics was introduced by Rodriguez-Iturbe and Valdes (1979), The authors derived GIUH in the framework of travel time distribution that explicitly accounts for the geomorphologic structure of a basin. Comparison of GIUH results for some real world basins with the IUH obtained by applying physically based rainfall-runoff model and discharge hydrographs showed remarkable similarity (Valdes et al., 1979). Many researchers have subsequently used the GIUH approach in modeling runoff for a watershed. Gupta et al. (1980) used probabilistic approach for determining functional form of a GIUH.

Natural Resources Conservation Service (NRCS) formerly known as Soil Conservation Services (SCS) developed techniques for rainfall-runoff analysis of a watershed and presented two important models namely, NRCS rainfall-runoff model and NRCS UH model. The NRCS rainfall-runoff model is based on the assumption that the ratio of actual runoff to potential runoff is equal to the ratio of actual retention to the potential retention of a watershed. The rainfall-runoff model is used to estimate runoff volume using precipitation volume and appropriate curve number (CN) for a watershed. $\mathrm{CN}$ is dimensionless number and is a function of land use, antecedent soil moisture content and other factors effecting runoff and retention of a watershed. NRCS derived an average dimensionless hydrograph and mass curve by analyzing a large number of natural UHs for watersheds varying widely in size and geographical locations (NRCS, 1958, 1971). In 1971 NRCS suggested that the dimensionless UH can be represented by an equivalent triangular hydrograph that enables defining the time base in terms of time to peak for the hydrograph. Based on the dimensionless UH and the equivalent triangular UH NRCS suggested a set of empirical equations for deriving curvilinear and triangular UH for a watershed. The NRCS UH model is a one parameter model and the UH is completely specified by the parameter, 'time of concentration'; NRCS suggested Lag 
method and the velocity or upland method for estimating time of concentration for a watershed. In Lag method time of concentration is obtained using hydraulic flow length, slope and maximum potential retention for a watershed while in velocity method time of concentration is derived using hydraulic flow length and flow velocity factor for a watershed. In the case of velocity method the velocity factor is estimated using land use and slope information in a predefine chart. The velocity factor is used to estimate time of concentration and UH for a watershed. Works on the application of NRCS model in deriving UH can be found in Reich (1965, 1968), Wu (1969), R.Y. Wang and Wu (1972), Mc. Cuen and Bondelid (1983), Sangal (1983), etc. Morgan et al., (1962) applied NRCS technique to 12 different watersheds obtaining results comparable with Snyder model and Commons \& Mitchell models. Mostaghimi et al., (1982) presented application of Cypress Creek model, Rational model, Chow model and NRCS model in small and medium watersheds located in Illinois. The authors found NRCS model performing better in estimating the peak flow rates for most of the watersheds. NRCS model is simple and can be calibrated using characteristic time of concentration value for a watershed. Researchers have used different techniques such as application of Kirpich formula (Kirpich, 1940), upland technique, etc. to estimate the time of concentration. Sorman, (1995); Rao et al., (1997); Kumar et al., (2002, 2007) and Sahoo et al., (2006) used excess-rainfall intensity and Kirpich formula to estimate the velocity parameter and time of concentration etc. for a watershed. Results obtained (Rao et al., 1997) indicates that use of excess-rainfall intensity in estimating dynamic parameter velocity may lead to inaccurate estimation of peak and time to peak of GIUH.

Geographic Information System (GIS) is a potentially effective tool in modeling spatially varied systems. Most of the geomorphologic parameters that are required for developing UH for a watershed are spatially varied and many authors have used GIS in estimating geomorphic IUH/UH for a watershed. Application of GIS techniques in deriving UH for a watershed can be seen in the works of Jain et al. (2000), Kavitha et al. (2004), Kumar et al. (2007) and Sarangi et al. (2007). The studies show that GIS is capable of handling spatially varied parameters and is effective in watershed modeling.

Kirpich formula allows estimating time of concentration for a watershed using length and slope characteristics. Characteristics flow velocity factor for a watershed is usually computed using estimated value for time of concentration. Time of concentration and characteristics velocity factor for a watershed are related thus by virtue of Kirpich formula velocity factor for a watershed can be estimated directly using length and slope characteristics for a watershed. In the present study NRCS model is applied with velocity factor estimated using length and slope characteristics to develop UH for a watershed. The model is applied to derive 1-hr UH for Madhura and Ghagra watersheds located in Barak basin in India. Drainage network for the watersheds and the geomorphologic parameters are estimated using 30m-ASTER DEM. Geomorphologic characteristics required to define velocity factor for the watersheds are estimated using GIS technique. Peak UH characteristic results obtained applying NRCS model is compared with earlier GIUH results, comparison of model performances show that NRCS model when used with velocity factor estimated using length and slope characteristics gives result similar to the GIUH model. 


\section{NRCS Model}

NRCS model uses land cover characteristics and slope data to estimate triangular and curvilinear UH for a watershed. A predefined chart prepared for different landcover characteristics is used to obtain velocity factor required for estimating time of concentration of a watershed. In some cases where land cover characteristics data are not available application of the NRCS model is difficult. Kirpich formula (Kirpich 1940) is a well known relationship useful in estimating time of concentration for a watershed. It allows estimating time of concentration using watershed length and slope characteristics. Time of concentration and the characteristics velocity factor are related and thus estimate for the later one can be obtained directly by using length and slope characteristics of a watershed. In the present case velocity factor estimated on the basis of length and slope characteristics is used with NRCS technique to develop UH for a watershed. Following steps may be used to develop UH using NRCS technique.

1. Estimate velocity factor for the watershed applying equation (1a) obtained by combining Kirpich formula and the velocity relationship given in equations (1b) and (1c) respectively.

$$
\begin{aligned}
& V=0.8562 L^{0.23} S^{0.385} \\
& t_{c}=0.01947 L^{0.77} S^{-0.385} \\
& t_{c}=\frac{1}{60}(L / V)
\end{aligned}
$$

Here, $t_{c}=$ time of concentration in min., $L=$ length of the stream/ditch from headwater to the outlet or main stream length in meter $(\mathrm{m})$, and $S=$ mean watershed slope $(\mathrm{m} / \mathrm{m})$ and $V=$ dynamic parameter velocity in $\mathrm{m} / \mathrm{s}$.

2. Time of concentration for the watershed may be obtained by using equation (1b) or by using equation (1c). It may be mentioned here the equation (1b) represents Kirpich formula and gives an estimate for time of concentration, $t_{c}$. Whereas, equation (1c) that is generally used in

NRCS model allows estimating time of concentration, $t_{c}$ on the basis of velocity factor estimated for the watershed.

3. With estimated value for time of concentration, $t_{c}$ Time to peak, $t_{p}$ as recommended by NRCS (NRCS, 1971) can be obtained employing the relationship.

$$
t_{p}=0.67 t_{c}
$$


The above relationship is obtained using $t_{R}=0.133 t_{c}$ and $t_{L}=0.6 t_{c}$ in equation (2b) as recommended by NRCS.

$$
t_{p}=\frac{t_{R}}{2}+t_{L}
$$

where, $t_{p}=$ time to peak in hours $(h) ; t_{R}=$ duration of the rainfall excess in hours; and $t_{L}=$ lag time in hours.

4. Assuming a triangular unit hydrograph the peak discharge $Q_{p}$ can be calculated using the relationship:

$$
Q_{p}=2.08\left(\frac{A \times Q}{t_{p}}\right)
$$

where, $Q_{p}=$ peak flow in $\left(\mathrm{m}^{3} / \mathrm{s}\right) ; A=$ area of the watershed in $\left(\mathrm{km}^{2}\right) ; Q=$ volume of direct runoff that equals to $1 \mathrm{~cm}$ for a unit hydrograph.

5. For a triangular hydrograph time base is computed using equation (4).

$$
\left(t_{b}\right)=2.67 t_{p}
$$

With estimated value for $Q_{p}, t_{p}$ and $t_{b}$ triangular $\mathrm{UH}$ for the watershed is developed.

\section{Study Area}

The model is applied to two ungauged watersheds, Madhura and Ghagra located in Barak basin in India to derive triangular UH applying NRCS technique. Barak basin has an approximate area of 26,193 $\mathrm{km}^{2}$. The selected watersheds, Madhura and Ghagra lie in the Cachar District of Assam with an approximate area of $349.43 \mathrm{~km}^{2}$ and $409.392 \mathrm{~km}^{2}$ respectively. Highest elevation in Madhura watershed is $1740 \mathrm{~m}$ above the mean sea level while highest elevation in Ghagra watershed is only $240 \mathrm{~m}$ above the mean sea level. Figure 1 and Figure 2 shows the delineated map of Madhura and Ghagra watersheds. Figure 3 and Figure 4 show the slope map for the watersheds. The Madhura watershed comprises of mountainous areas, small patches of steep terrains and little low land areas while, Ghagra watershed comprises of vast low land areas with few hills. Main stream in Madhura and Ghagra watersheds are $52.61 \mathrm{~km}$ and 48.93 $\mathrm{km}$ long respectively. Highest order stream length for these watersheds is measured to be $14.59 \mathrm{~km}$ and $19.784 \mathrm{~km}$ respectively. Stream network developed for these watersheds are used to estimate various geomorphologic parameter for the watersheds. 


\section{Macrothink}

\section{Applications}

Application of the NRCS technique is made to derive UH for ungauged watersheds in Barak Basin in India. Watershed geomorphologic characteristics are estimated using GIS supported techniques. Advanced Spaceborne Thermal and Reflection Radiometer (ASTER) data useful for quantifying watershed characteristics are obtained from the website (http:// www. gdem.aster.ersdac.or.jp). The downloaded DEM for the watersheds is used with GIS software ArcMap to delineate watershed area and to develop slope map, drainage network map, etc. Using DEM flow direction and flow accumulation maps for the watersheds are developed. To develop stream network a threshold value that gives the minimum number of upslope cells contributing to a downstream cell required for considering the downstream cell to be a part of the stream network is used. Trials with different threshold values for the watershed is conducted and based on the test results a threshold value of 500 is used to develop stream networks for the watersheds. With the drainage network map as input and using Strahler's stream ordering law (Strahler, 1964) the drainage network for the watersheds are ordered applying GIS stream ordering tool. Figure 1 and 2 shows the ordered drainage network for Madhura and Ghagra watersheds respectively.

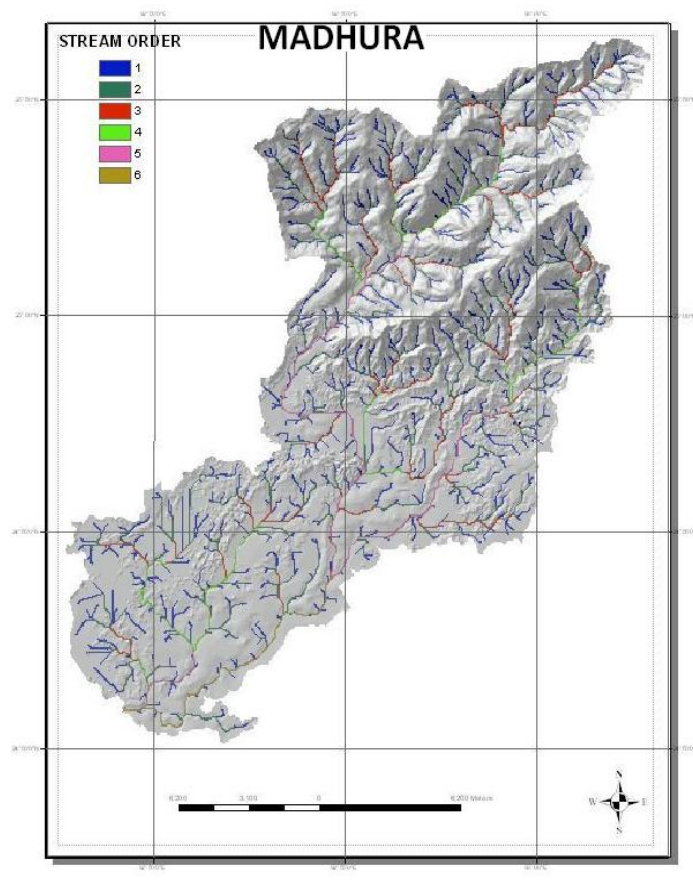

Figure 1. Madhura watershed showing different streams

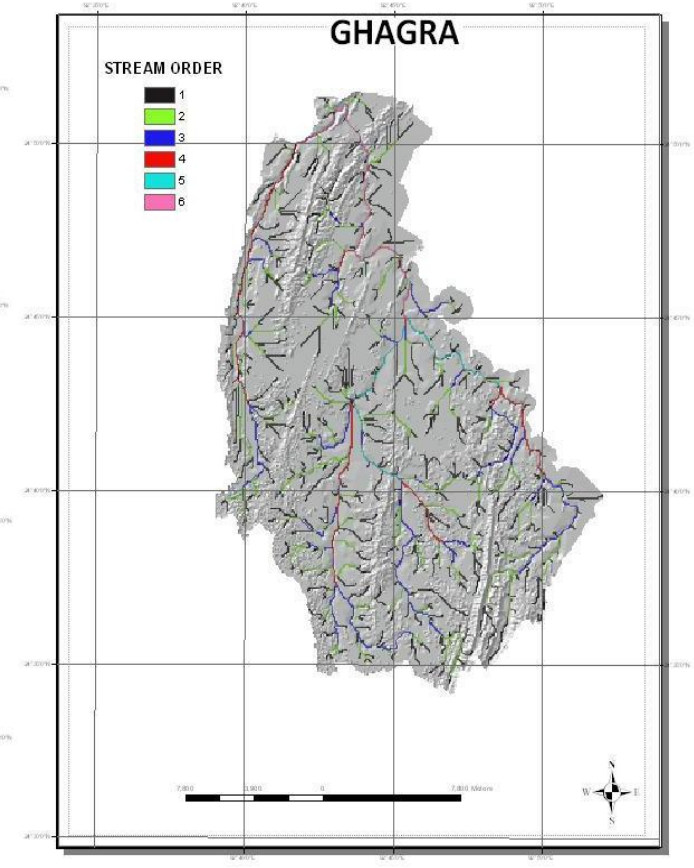

Figure 2. Ghagra watershed showing different streams 


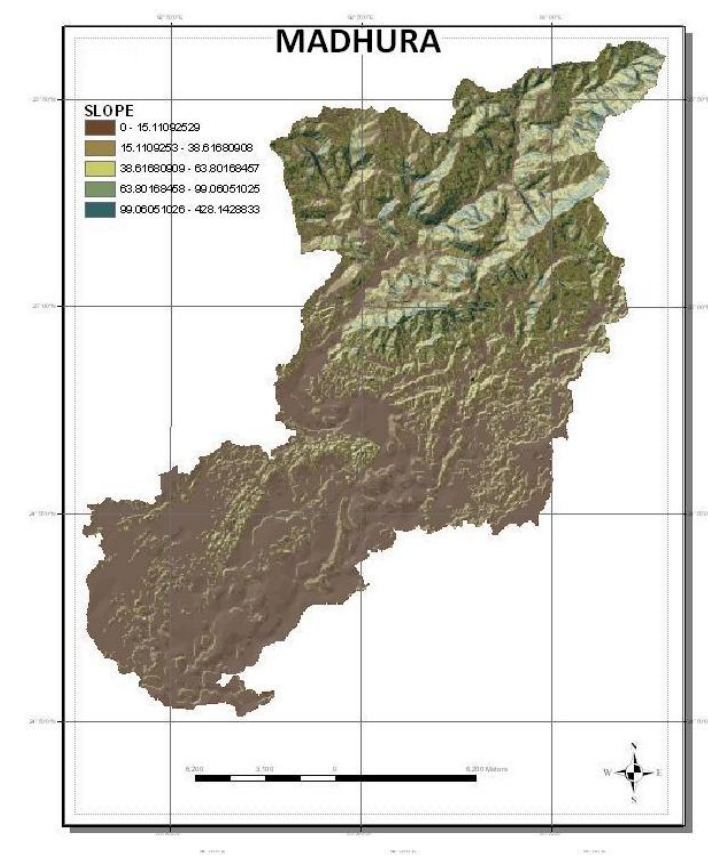

Figure 3. Slope map for Madhura watershed

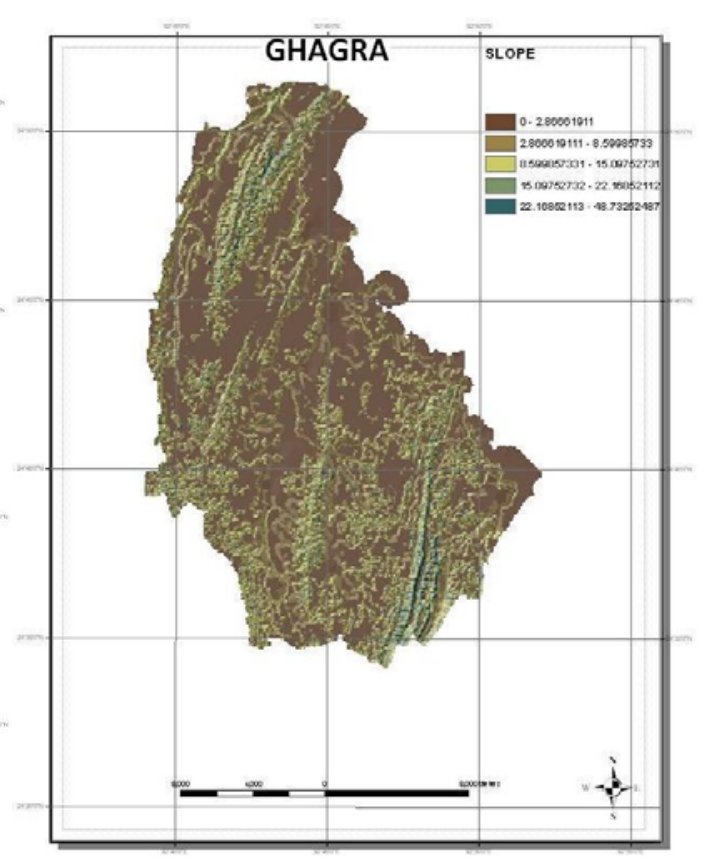

Figure 4. Slope map for Ghagra watershed

On the basis of the ordered drainage network, areas drained and stream lengths for different stream orders are obtained. Horton's geomorphologic parameters (Horton, 1945) $R_{A}, R_{B}$ and $R_{L}$ for the watershed are estimated graphically by plotting average areas drained, stream numbers and average stream length respectively against the stream orders. Absolute slope value for the best fit line is taken to compute the ratios. Graphical representations showing best fit line is used for computing $R_{A}, R_{B}$ and $R_{L}$ for Madhura and Ghagra watersheds. The best fit lines for Madhura and Ghagra watersheds are shown in Figures 5 and 6 respectively. Estimated geomorphologic parameters for Madhura and Ghagra watersheds are given in Table 1. Estimated watersheds mean slope and main stream length values are used in equation (1a) to obtain velocity factor for Madhura and Ghagra watersheds respectively. The velocity parameter estimated for Madhura and Ghagra watersheds are $6.391 \mathrm{~m} / \mathrm{s}$ and $4.196 \mathrm{~m} / \mathrm{s}$ respectively. The parameters values listed in Table 1 are used with the NRCS model to develop triangular based $1 \mathrm{hr}$ UHs for the watersheds. UH characteristics such as peak discharge, $Q_{p}$; time to peak, $t_{p}$; and base time, $t_{b}$ are computed using equations 3 , 2a and 4 respectively. Peak discharge, time to peak, and base time defining the triangular UH for the Madhura watershed is obtained as $528.73 \mathrm{~m}^{3} / \mathrm{s}, 1.5 \mathrm{hrs}$ and $4.1 \mathrm{hrs}$ respectively and for Ghagra watershed the values are $392.024 \mathrm{~m}^{3} / \mathrm{s}, 2.2 \mathrm{hrs}$ and $5.8 \mathrm{hrs}$ respectively; the UH results are listed in Table 2. Triangular based UH for Madhura and Ghagra watersheds are given in Figure 7 and Figure 8 respectively. To derive UH for the watersheds velocity factor is estimated using length and slope characteristics for the watersheds. The technique of estimating velocity factor for a watershed using length and slope characteristics is tested using a known hydrograph for Burhner watershed in India with satisfactory results (Jotish et al., 2011). NRCS is a single 
parameter model and characteristics of the UH are estimated on the basis of the parameter, $t_{c}$ only. As accuracy of the estimated UH depends on the value of $t_{c}$ used, accurate estimation of $t_{c}$ value is essential and it requires careful selection of suitable relationship giving $t_{c}$ value and an improved technique for parameter estimation. On the other hand, GIUH incorporates more number of watershed physical characteristics in deriving IUH/UH for a watershed. The GIUH model parameters can be easily measured and can also be obtained using topo map, remote sensing data, etc. The technique is simple and more realistic as it incorporates many physical characteristics of a basin. NRCS model efficiency are evaluated by comparing with the GIUH results.

The GIUH model given by equations (5), (6) and (7) are used to estimate peak discharge, time to peak and time base of the IUH.

$$
\begin{gathered}
q_{p}=1.31 R_{L}^{0.43}\left(V / L_{\Omega}\right) \\
t_{p}=0.44\left(L_{\Omega} / V\right)\left(R_{B} / R_{A}\right)^{0.55}\left(R_{L}\right)^{-0.38} \\
t_{b}=2 / q_{p}
\end{gathered}
$$

Here, $q_{p}=$ peak flow in units of inverse hours $\left(h^{-1}\right) ; t_{p}=$ time to peak in hours $(h)$; $V=$ dynamic parameter velocity $(\mathrm{m} / \mathrm{s}) ; L_{\Omega}=$ length of the highest order stream in the watershed $(\mathrm{km})$; and $R_{L}, R_{B}$ and $R_{A}=$ Horton's length ratio, bifurcation ratio and area ratio respectively. To develop IUH for Madhura and Ghagra watersheds dynamic parameter velocity estimated for the watersheds and listed in Table 1 are used in equations (5) and (6). $q_{p}, t_{p}$ and $t_{b}$ values obtained for Madhura and Ghagra are $0.79 h^{-1}, 0.7 h$ and $2.52 h$ and $0.38 h^{-1}, 1.53 h$ and $5.32 h$ respectively. Using estimated peak characteristics IUH for the watersheds are developed. IUH ordinates for the watersheds at an interval of $0.1 \mathrm{~h}$ are computed and lagged applying S-Curve technique to derive $1 \mathrm{hr} \mathrm{UH}$ for the watersheds. 1-hr UH estimated for Madhura and Ghagra watersheds using GIUH technique are shown in Figure 7 and Figure 8. Considering GIUH results as standard percentage deviation in peak discharge, $Q_{p}$ and time to peak, $t_{p}$ values for NRCS model are computed and are given in the table. It may be seen from the listed results that the maximum and minimum deviation in peak values is around $23 \%$ and $-13 \%$ only. The estimated peak characteristic values obtained by applying NRCS and GIUH models are almost same and are close to earlier reported results. The study shows that NRCS model may be used with velocity factor estimated on the basis of length and slope characteristics to derive UH for a watershed. The technique of estimating velocity factor on the basis of length and slope parameters is beneficial for cases where land cover characteristic are not available. 
Table 1. Geomorphologic characteristics for Madhura and Ghagra watersheds

\begin{tabular}{|c|c|c|c|c|c|c|c|c|c|}
\hline Watershed & \multicolumn{9}{|c|}{ Watershed characteristics } \\
\hline & $\begin{array}{l}\text { Order } \\
(\Omega)\end{array}$ & $\begin{array}{l}\text { Area } \\
A\left(\mathrm{~km}^{2}\right)\end{array}$ & $\begin{array}{l}\text { Highest } \\
\text { Order } \\
\text { Stream } \\
\text { Length } \\
\left(L_{\Omega}\right) \\
(\mathrm{km})\end{array}$ & $\begin{array}{l}\text { Area } \\
\text { Ratio } \\
\left(R_{A}\right)\end{array}$ & $\begin{array}{c}\text { Length } \\
\text { Ratio } \\
\left(R_{L}\right)\end{array}$ & $\begin{array}{l}\text { Bifur } \\
\text { cation } \\
\text { Ratio } \\
\left(R_{B}\right)\end{array}$ & $\begin{array}{l}\text { Main } \\
\text { stream } \\
\text { length } \\
(L) \\
(\mathrm{km})\end{array}$ & $\begin{array}{l}\text { Average } \\
\text { slope } \\
(S) \\
(m / m)\end{array}$ & $\begin{array}{l}\text { Average } \\
\text { Velocity } \\
(V) \\
(\mathrm{m} / \mathrm{s})\end{array}$ \\
\hline Madhura & 6 & 389.43 & 14.589 & 4.305 & 2.125 & 3.826 & 52.609 & 0.28 & 6.391 \\
\hline Ghagra & 6 & 409.39 & 19.784 & 3.90 & 2.022 & 3.640 & 48.930 & 0.098 & 4.196 \\
\hline
\end{tabular}

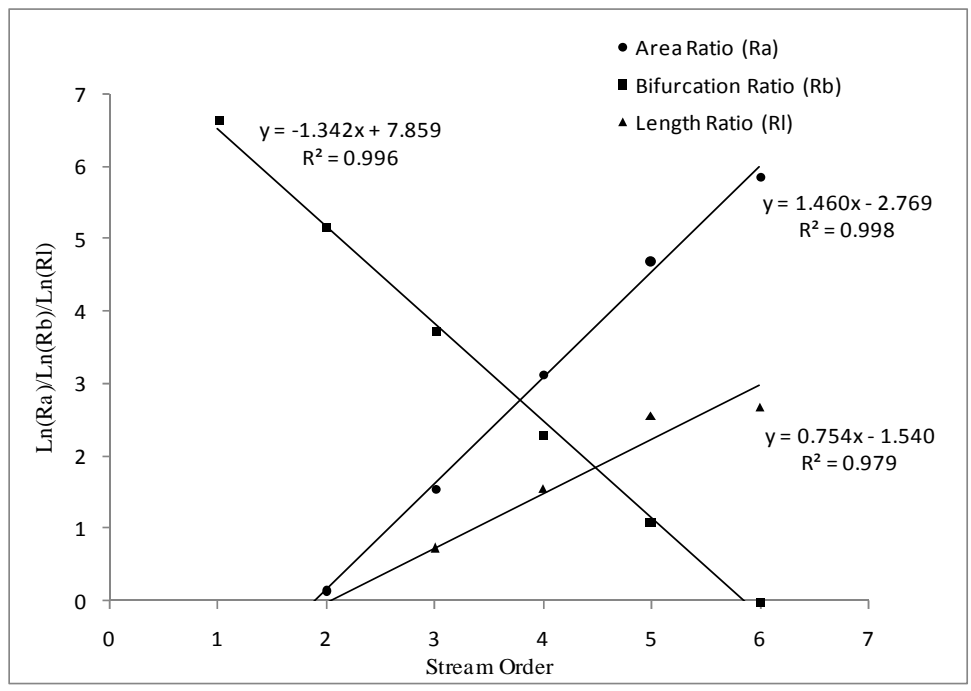

Figure 5. Estimation of ratios $R_{a}, R_{b}$ and $R_{l}$ for Madhura watershed.

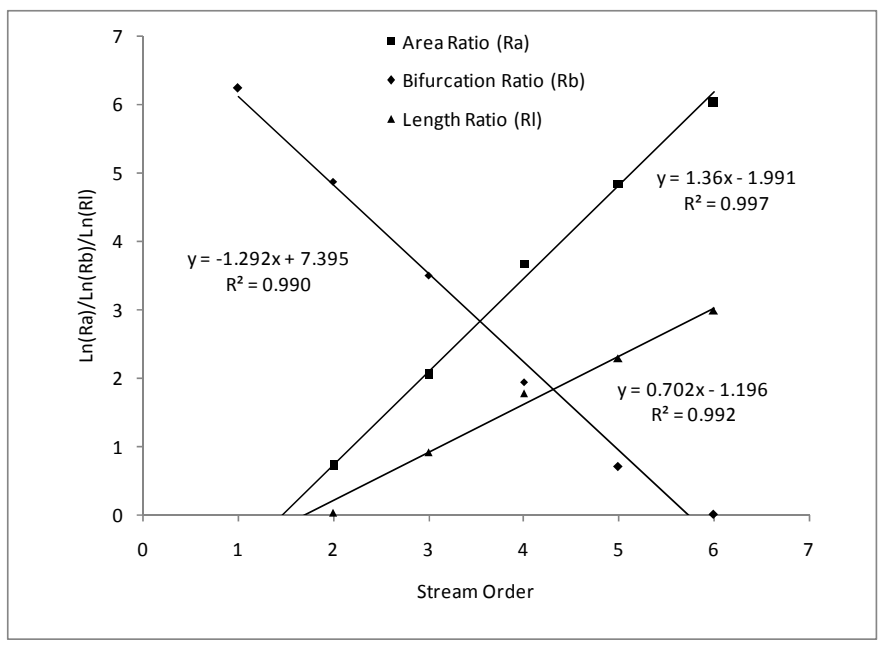

Figure 6. Estimation of ratios $R_{a}, R_{b}$ and $R_{l}$ for Ghagra watershed 


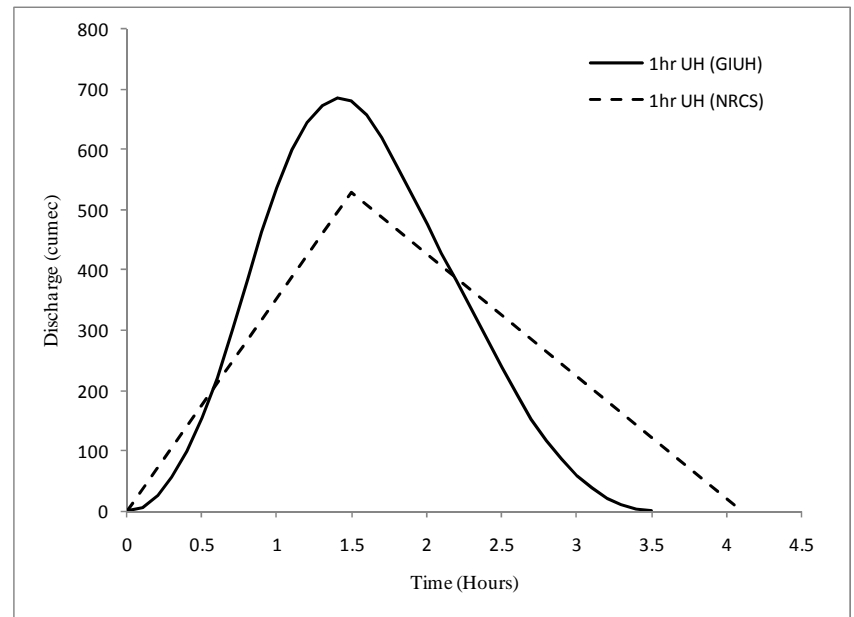

Figure 7. Comparison of the derived UH for Madhura watershed

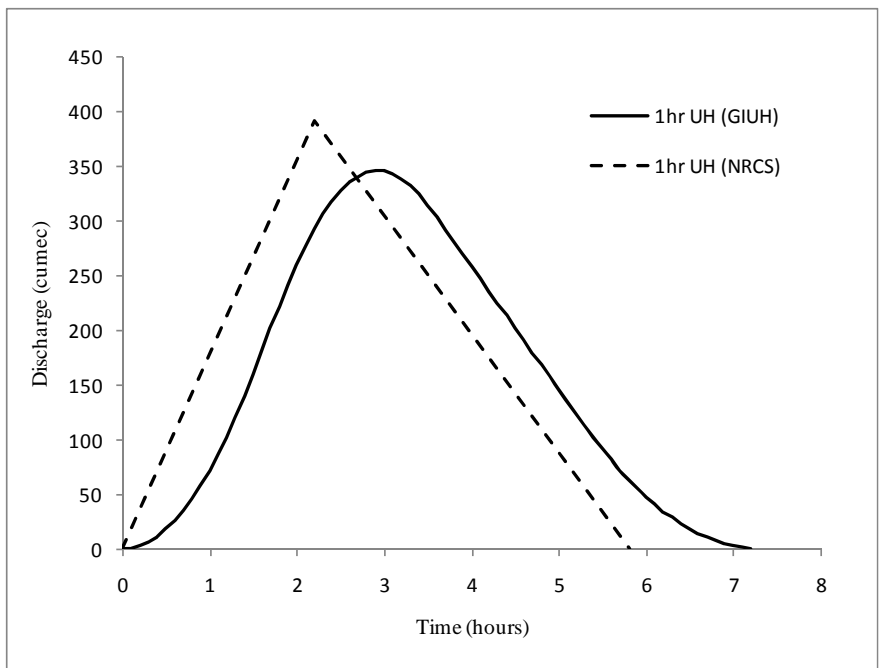

Figure 8. Comparison of the derived UH for Ghagra watershed

Table 2. Comparison of model performances

\begin{tabular}{|c|c|c|c|c|c|c|}
\hline \multirow[t]{2}{*}{ Watershed } & \multicolumn{2}{|l|}{ GIUH } & \multicolumn{2}{|l|}{ NRCS } & \multicolumn{2}{|c|}{$\begin{array}{l}\text { Percent difference } \\
\text { (\%) }\end{array}$} \\
\hline & $\begin{array}{l}\text { Peak } \\
\text { discharge, } \\
Q_{p} \\
\left(m^{3} / s\right)\end{array}$ & $\begin{array}{l}\text { Time to } \\
\text { peak, } \\
t_{p} \\
(h r s)\end{array}$ & $\begin{array}{l}\text { Peak } \\
\text { discharge, } \\
Q_{p} \\
\left(m^{3} / s\right)\end{array}$ & $\begin{array}{l}\text { Time to } \\
\text { peak, } \\
t_{p} \\
(h r s)\end{array}$ & $\begin{array}{l}\text { Peak } \\
\text { discharge, } \\
Q_{p} \\
\left(m^{3} / s\right)\end{array}$ & $\begin{array}{l}\text { Time to } \\
\text { peak, } \\
t_{p} \\
(h r s)\end{array}$ \\
\hline Madhura & 686.24 & 1.4 & 528.73 & 1.5 & 22.95 & -7.14 \\
\hline Ghagra & 346.86 & 2.9 & 392.02 & 2.2 & -13.02 & 24.14 \\
\hline
\end{tabular}




\section{Conclusion}

In the present study NRCS model is applied with velocity factor estimated using length and slope characteristics to develop UH for a watershed. As given by Kirpich formula and velocity relationship characteristics flow velocity for a watershed can be estimated directly by using length and slope values. Verification of the technique employed to estimate velocity parameter was tested earlier with satisfactory results. The model has been applied to derive 1-hr UH for Madhura and Ghagra watersheds located in Barak basin in India. Drainage network for the watersheds and the geomorphologic parameters are estimated using 30m-ASTER DEM. Length and average slope for the watersheds are estimated using GIS technique. Peak UH characteristics results obtained applying the model is compared with earlier GIUH results, comparison of the model performances show that NRCS model when used with velocity factor estimated using length and slope characteristics gives similar results. Incorporation of new technique for velocity estimation in NRCS model is beneficial to ungauged watersheds for which land cover characteristics data are not available.

\section{References}

Bernard, M. (1935). An approach to determinate stream flow. Trans., Am. Soc. Eng., 100, 347-362.

Boyd, M. J., Bates, B. C., Pilgrim, D. H., \& Cordery, I. (1987). WBNM: A general runoff routing model-Programs and user manual. Water Research Laboratory Rep. No. 170, Univ. of New South Wales, Kensington, Australia.

Boyd, M. J., Pilgrim, D. H., \& Cordery, I. (1979). A storage routing model based on catchment geomorphology. J. Hydrol., 42(3-4), 209-330.

Gupta, V. K., Wayamiri, F. D., Wang, C. T. (1980). A representation of an instantaneous unit hydrograph from geomorphology. Water Resour. Res., 16(5), 855-862.

Horton R. E. (1945). Erosional development of streams and their drainage basins: hydrophysical approach to quantitative morphology. Bulletin of Geological Society of America., 56, 275-370.

Jain, S. K., Singh, R. D., \& Seth, S. M. (2000). Design flood estimation using GIS supported GIUH approach. Water Resour. Mgmt., 14, 369-376.

Jotish, N., Choudhury, P., Nazrin, U., \& Victor, K. S. (2011). A Geomorphological based rainfall-runoff model for ungauged watersheds. International Journal of Geomatics and Geosciences, 2(2), 676-687.

Kavitha, K., Rao, B. N. M., \& Umamahesh, N. V. (2004). Prediction of runoff from ungauged watersheds a GIS approach. International Conference on advanced modeling techniques for sustainable management of water resources. (AMTSMW-2004), E, 320-325.

Kirpich, Z. P. (1940). Time of concentration of small agricultural watersheds. Civ. Engg., 10(6), 362. 
Kumar, R., Chatterjee, C., Lohani, A. K., Sanjay, K., \& Singh, R. D. (2002). Sensitivity analysis of the GIUH based clark model for a catchment. Water Resour. Mgmt., 16, 263-278.

Kumar, R., Chatterjee, C., Singh, R. D., Lohani, A., \& Sanjay, K. (2007). Runoff estimation for an ungauged catchment using geomorphological instantaneous unit hydrograph (GIUH) models. J. Hydro. Processes, 21, 1829-1840.

McCuen, R. H., \& Bondelid, T. R. (1983). Estimating unit hydrograph peak rates factors., ASCE J. of Irrigation and Drainage Engineering., 109(2), 238-50.

Morgan, P. E., \& Johnson, S. M. (1962). Analysis of synthetic unit graph methods. Proceedings of the American Society of Civil Engineers, J. of the Hydraulics Division 88(HY5),199-220.

Mostaghimi, S., \& Mitchell, J. K. (1982). Peak runoff model comparison on central Illinois. Water Resources Bulletin, 18(1), 9-13.

Natural Resources Conservation Service. (1958). Hydrology., SCS National Engineering Handbook, section 4, U.S. Department of Agriculture, Washington, D.C.

Natural Resources Conservation Service. (1971). (1958). Hydrology., SCS National Engineering Handbook, section 4, U.S. Department of Agriculture, Washington, D.C.

Rao, N. B., Bhagabat, P. Parida, \& Atul Kumar Nyak. (1997). Flood estimation for ungauged catchments using the GIUH. J. Water Resour. Plng. and Mgmt., ASCE, 123(4), 228-238.

Reich, B. M. (1965). Estimating flood peaks from small South African catchments., Journal of Hydrology, 3, 231-53.

Reich, B. M. (1968). Rapid flood-peak determination of small watersheds., Trans. Of the ASAE., 11, 448-51.

Rodriguez-Iturbe, I., Valdes, J. B. (1979). The geomorphologic structure of hydrologic response. Water Resour. Res., 15(6), 1409-1420.

Sangal B. P. (1983). Practical method of estimating peak flow. ASCE J. of Hydraulic Engineering, 109(4), 549-63.

Sarangi, A., Madramootoo, C. A., Enright, P., \& Prasher, S. O. (2007). Evaluation of three unit hydrograph models to predict the surface runoff from a Canadian watershed. Water Resour. Mgmt., 21, 1127-1143.

Shaoo, B., Changranath, Chatterjee, Narendra, S. Raghuwanshi, Ranjendra Singh \& Rakesh Kumar. (2006). Flood estimation by GIUH-based clark and nash models. J. Hydr. Engg., ASCE, 11(6), 515-525.

Snyder, F. F. (1938). Synthetic unit graphs. Trans., Am. Geophys. Union, 19, 447-54.

Sorman, A. U. (1995). Estimation of peak discharge using GIUH model in Saudi Arabia. J. Water Resour. Plng. and Mgmt., ASCE, 121(4), 287-293. 
Strahler, A. N. (1964). Quantitative geomorphology of drainage basins and channel networks. Section 4 - II, Handbook of Applied Hydrology, by V. T. Chow, McGraw-Hill, New York.

Taylor, A. B., \& Schwarz, H. E. (1952). United hydrograph lag and peak flow related to basin characteristics. Trans., Am. Geophys. Union, 33(2), 235-246.

Valdes, J. B., Fiallo, Y., \& Rodriquez-Iturbe, I. (1979). A rainfall-runoff analysis of geomorphologic IUH. Water Resour. Res., 15(16), 1421-1434.

Wang, R. Y., \& Wu, I. P. (1972). Characteristics of short-duration unit hydrograph. Trans. of the American Society of Agricultural Engineers., 15, 452-56.

Wu, I. P. (1969). Flood hydrology of small watersheds: evaluation of time parameters and peak discharge. Trans. of the American Society of Agricultural Engineers., 12, 655-60 and 663.

\section{Copyright Disclaimer}

Copyright reserved by the author(s).

This article is an open-access article distributed under the terms and conditions of the Creative Commons Attribution license (http://creativecommons.org/licenses/by/3.0/). 